\title{
Tradition culinaire au Myanmar... Vous avez dit tradition?
}

\section{François Robinne}

\section{(2) OpenEdition \\ 1 Journals}

Édition électronique

URL : https://journals.openedition.org/tc/384

DOI : $10.4000 /$ tc.384

ISSN : 1952-420X

Éditeur

Éditions de l'EHESS

Édition imprimée

Date de publication : 1 avril 1999

ISSN : 0248-6016

Référence électronique

François Robinne, "Tradition culinaire au Myanmar... Vous avez dit tradition ? ", Techniques \& Culture [En ligne], 31-32 | 1999, mis en ligne le 26 octobre 2005, consulté le 29 septembre 2022. URL : http:// journals.openedition.org/tc/384 ; DOI : https://doi.org/10.4000/tc.384

Ce document a été généré automatiquement le 29 septembre 2022.

Tous droits réservés 


\section{Tradition culinaire au Myanmar... Vous avez dit tradition?}

François Robinne 